\title{
The Long March Through the Patriarchal Institutions: A Dialogue Between Rosi Braidotti and Nina Lykke
}

\author{
Lea Skewes ${ }^{1 *}$, Stine Willum Adrian ${ }^{2}$
}

Published: September 1, 2021

\begin{abstract}
Doing feminist work from within patriarchal institutions comes with unique challenges. We invited two activists and feminist studies professors, Rosi Braidotti and Nina Lykke, to reflect on feminists' long march through patriarchal university institutions. Concretely, we asked them to reflect upon three themes. Firstly, we asked them to situate themselves and their work - and reflect upon what it takes to do feminist work which troubles mainstream epistemologies. Secondly, we asked them to explore how the conditions for feminist research have changed over time - and what the current neoliberal and right-wing backlash does to feminist research. And finally, we asked how coming of age might have influenced them, and how they looked upon intergenerational exchanges in the feminist movement. The aim of the dialogue was to look back at how the feminist studies movement in academia emerged, while at the same time looking forward to explore which new political and ideological conditions have arisen and how these might affect future possibilities for conducting feminist research within academia.
\end{abstract}

Keywords: Braidotti, Lykke, patriarchal institutions, feminist studies, feminist revolutions

\section{THE CONTEXT FOR THE DIALOGUE}

The dialogue between Rosi Braidotti and Nina Lykke took place at Aarhus University in Denmark in September 2018. The event was organised by the Gendering in Research Network and the three editors of the special issue of Women, Gender and Research called Feminist STS at Worke (Adrian, Skewes and Schwennesen, 2018). In this special issue, Lykke featured with an interview about how her academic career had been entangled with her activist intentions of rethinking knowledge production and epistemology (Skewes and Adrian, 2018). We invited yet another inspirational activist and feminist researcher, Braidotti to join in the reflections about her experiences with the long march through the patriarchal institutions.

Braidotti and Lykke have collaborated in multiple ways throughout their careers. Together they edited Between Monsters, Goddesses and Cyborgs (1996). They have also been among the driving forces in a multitude of key feminist research and teaching networks in Europe, such as the European feminist curriculum development organisation Athena, which grew into the European Association for Feminist Research and Teaching At Gender (https://atgender.eu/), as well as the Noise Summer School (https://graduategenderstudies.nl/education/noisesummer-school/), gathering feminist students for summer schools annually since 1994. Furthermore, they have collaborated within the framework of a Marie Curie network for feminist PhD education GENDERGRADUATES. All of these networks and collaborations across disciplines, universities and countries illustrate their passionate desire to establish a solid basis for feminist researchers.

Braidotti and Lykke are close friends. Their academic careers have in different ways been dedicated to the struggle to expand the fragile spaces of academia's interdisciplinary feminist borderlands and included transgression of national borders. Both are openly married lesbians, Lykke widowed since 2014.

Braidotti describes herself as having led a nomadic life-born in Italy, growing up as a migrant in Australia, only to move to Paris in order to complete her $\mathrm{PhD}$ and start her academic work in the Paris campus of Columbia

${ }^{1}$ The event was made possible through funding from Interacting Minds Centre at Aarhus University and the Danish feminist journal, Women, Gender and Research. 
University at Reid Hall. Braidotti built most of her career in Utrecht in the Netherlands, where she was appointed founding professor of women's studies in 1988 a position she has occupied ever since. This migrant, nomadic and multi-lingual condition has inspired her theoretical thinking (Braidotti, 1994; 2011). Braidotti situates herself as grounded in one discipline namely continental philosophy (with inspirations from Foucault, Irigaray and Deleuze), although she adopts an interdisciplinary feminist approach influenced by literature, media and cultural studies. However, she is neither employed by the discipline of philosophy, nor especially loyal to it. Braidotti has systematically practiced dis-identification from and dis-obedience to any discipline and has written extensively on the 'undutiful daughters' of the academy. In other words, she has invested her intellectual energy in the making of transversal feminist theories.

Lykke has had her academic base in two Scandinavian countries: first approximately 20 years in Denmark, at the University of Southern Denmark, and the following 20 years, at The Unit of Gender Studies at Linköping University in Sweden, where she now is an Emerita Professor. In this sense, Lykke has had two academic platforms, and despite being a Danish citizen, she has felt most at home academically in Sweden where her endeavours to implement feminist agendas in academia has met fewer obstacles than in Denmark. Even though Lykke started out with a degree in literary studies, she considers herself a transdisciplinary scholar, and a key part of her work has been committed to breaking down disciplinary borders in order to achieve new types of trans- and postdisciplinary knowledges which, resonate better with feminist epistemologies.

\section{DIALOGUE}

\section{Feminist researchers situated in a historical and political context}

BRAIDOTTI: It is like being in dialogue with myself, being in dialogue with Nina, these are parallel, though distinct, lives. I think we need more parallel life stories to account for our generation. I actually co-wrote one experimental parallel text with three of my best Italian friends and it was a phenomenal experience (Braidotti et al., 2003). It is very illuminating to have the personal and professional narratives of several women of the same generation running alongside each other. But I must admit that it is a challenge to look back upon your life, while you are still active. It requires a balancing act between professional assessment, the personal affects and the depersonalised accounts of multiple - and often contradictory - experiences and practices.

One of the hesitations I have in providing my account is that I fear superimposing a retrospective sense of order into a life-itinerary that was anything but linear. Let me give you an example: When I turned 60 in 2014, I was honoured to have a volume of essays collected in my memory (Blaagaard and van der Tuin, 2014). Writing my own contribution to it, was like experiencing yourself as already gone, while you were still alive. That stance required an impersonal or depersonalised look upon my life-work, as if in fact it did not only belong to me.

That sensation allowed me to focus on a set of reflections on death, that I had started writing in 2006 in Transpositions. Being a vital new materialist, I do not go into the rhetoric of vulnerability easily, but rather defend an affirmative way of processing pain and fear. Precisely because of that affirmative ethics, however, I am capable of talking openly about death - even the thought of my own death - unsentimentally, but also uncynically. Death being the event that you can only prepare in life, coincides with the project of living an ethically and politically just life. In some respect, that postface is my literary and intellectual testament. Writing as if I had already gone, turned into one of the most extraordinary, fascinating, generative, difficult things to do. While it pained me, it also cheered me up immensely.

My feminist politics, framed by consciousness-raising, affirmative ethics and the politics of location is coextensive with my intellectual life project. It has led me to foreground the question of subjectivity in both my theoretical work and my institutional practice. The golden rules of my feminist method are: the dis-identification from institutional and disciplinary formations, from socially enforced identities and familiar representations. Disidentifications enact a critical distance from the power structures at work in the process of becoming subjects. But they also pave the ground for alternative spaces to emerge as experiments in becoming. I remain convinced that the politics of location, based on materially grounded intersectionality, is feminism's greatest theoretical and methodological contribution. It stresses the need to speak from somewhere grounded and accountable and to produce knowledge as an embodied, embedded, affective and relational entity.

To position myself, then: I belong to the generation of the baby boomers and although I am at the tail end of it, I was shaped by the Cold War, and by a technological universe that looks primitive in relation to today's internetframed world. When I try to situate myself, these two events are the two grand canyons between me and the younger generations: the Cold War and no internet.

This was a Europe composed only of seven countries, in a world ideologically split in two opposing camps, pointing nuclear weapons at each other. Strict borders with visa systems limiting travel dramatically. Without adhering to strict visa regulations, you could not enter the Soviet Empire, which extended across Eastern Europe. 
But we all did make a point of crossing that border legally. Going to West Berlin became an act of resistance. But it felt like visiting another planet. The differences were staggering. Of course, I moved to Australia in 1970 and my experience of migration added another, ever sharper dimension, to the sense of mobility and the experience of hard borders. The anti-Vietnam moratorium was even stronger in Melbourne than in my Italian birthplace, as was the sense of a lethal Cold War confrontation. So across multiple sites - Italy, Australia, then again Europe - the world I grew up in, was so other than the globally interlinked contemporary world.

Our collective technological power was laughable - not only did we not have the internet, but we even lacked the most basic phone connections. These limitations were not solely negative, because they allowed us to spend a lot of time with our friends. We functioned in groups, swarms and movements. In some ways we did not suffer as much from stress due to the constant inter-connectivity, the information overload, and the pressure to make consumer-oriented choices and express opinions.

Role-models for feminist practice were few and far between. One of my role models was the existentialist philosopher Simone de Beauvoir - because I fell in love with philosophy as a literary and textual genre very early. Then, growing up in Melbourne, I changed language and also political culture, becoming closer to the Englishspeaking world. Firstly, I was fortunate enough to have at feminist university supervisors of the calibre of Genevieve Lloyd, who is a life-long influence and role-model and Maurita Harney, a close friend. Secondly, there was the Australian women's movement: I admired Germaine Greer - an incredible woman, quite a contrarian, but unique. I do not agree with her current transphobic position, but her earlier work inspired me. Internationally, Kate Millet mattered to me, because she represented the radical wing, and because she dared to speak up about her multi-directional sexual orientations. Millett was a Rhodes Scholar who did her PhD at Oxford, on a topic that we would later turn into women's studies. Kate Millett's Sexual Politics (1970) is one of the first feminist PhDs. In her book she summaries the totality of available feminist knowledge in 1964-66. She covers it all. Her dissertation has chapters on psychology, history, sociology, philosophy, literature - everything! Similarly, when I did my PhD in philosophy at the Sorbonne in the late 1970s, there were three books on feminist philosophy. That part of the research was quickly done. We were just so few then, and yet we knew that there would be strength in numbers.

Compare that situation to today: now there is a mountain of scholarly material - from Millet's Sexual Politics to the feminist glossaries, readers, anthologies or the multi-volume Routledge Encyclopaedia of Women's and Gender Studies. I mean, it's incredible to think of what we have produced as a collective community of scholars in 30 to 40 years! Feminist knowledge is one of the greatest epistemological revolutions of the second half of the twentieth century. We have redesigned the parameters of knowledge.

In a sense there was only one way for my generation to go, and that was forward, kicking, fighting and saying no! Civil disobedience! The rebellion was genuine - there was a clear sense that we were both carrying and being carried by history. The conviction that we were a force of progress was overwhelming. Baby boomers are demographically very numerous. And we shared the sense that we were what was happening, that we were shaping the future by upsetting the present.

That awareness had implications for the academic work I did. Like many in my peer group, I never had a career plan. I struggled with the academic institutions, contesting, questioning and making things up as I went. I respected the rules of academic work and upheld the highest possible standards, but not without criticism of the lack of inclusive objectivity and the pseudo-universalisms that structured research. We were politicised and accustomed to working together in groups and collectives. Moreover, we were carried by a growing economy, in a world order that was visibly cracking, as the youth rebellion and the anti-colonial movements showed. Retrospectively, I would say that we were also carried by a massive set of crises in the transformation of capitalism from an industrial to a post-industrial society. But we had a sense that we were agents of progressive history: popular culture was on our side, we had the music, we had the technology, we had plenty of ideas about the future. There was a great feeling of excitement and a sense of possibility. Not having career plans left many of us open to the risk of long periods of un- or under-employment. For many of my friends this translated into a marginal social existence. But my role models like de Beauvoir never had a career plan, either.

Money was not a priority. In fact, we, like the good old socialists, we despised it. It was perfectly okay for my generation to be poor. I spent most of my youth buying second-hand clothes at flea markets. This is before brands took over the market. This is before mobile phones, Instagram, and the coercion of the branded 'body beautiful' culture. The turning point was the punk revolution, which ruled that the way you dressed and looked, expresses not only your politics, but also your world-view. The punk revolution, however, soon became pretty expensive and turned into a brand of its own. Before that, it was fine to be poor. Everybody was, and it did not matter, partly because we did not need advanced technology: no iPhone, no iPad. Our generational relationship with commodification and money needs again to be contextualised. Clearly, by becoming tenured professors - as pioneers in women's and gender studies - some of us ended up building amazing careers, though this was never planned. At heart we remain sceptical about money and capital. 
But the historical contradiction of a radical generation that becomes a sort of counter-establishment, is real and I take it very seriously. In this respect, let me add that together with my marriage partner Anneke Smelik, we have made a testament on behalf of Utrecht University (ROSANNA Foundation). We are giving away all of our money to a foundation in the university that will create scholarships for women. It is kind of gesture of coherence that reasserts our critical distance from money in some respects, while honouring our achievements and social role. It is also a statement of intergenerational solidarity, because we are tenured radicals that made careers out of being radical. That is our historical contradiction.

LYKKE: I did not have a career plan either, and I ended up having three careers or non/careers. I have just entered into my third non/career, which is being retired and enabled by my retirement money to act as an independent researcher, which I really love. The first non/career came, from our being among the post WWII baby boomers. For me, this first non/career was also intertwined with the students' movement of 1968. I happened to study at a department at the University of Copenhagen - the Department for Literary Studies - which was one of the hubs for the students' revolt in Denmark in the early 1970s. Moreover, there was a strong feminist presence at the Department. The (back then) well-known feminist slogan of 'being tired of making tea to the revolution' led us to the feminist movement and gave room for our engagement in feminist socialist activism. In these hubs there was a strong 'do it yourself ethos. A bit like: 'Disrupt all authoritarian ways of doing Academia! Do it democratically! Do it differently! Do it yourself! Make your own curriculum! Decide what you find important to study from an activist perspective!' I think it was a time where everything was up for grabs, or, at least, we felt that everything was up for grabs.

On the one hand, there was the Cold War, the Vietnam war, apartheid in South Africa, the Israeli occupation of Palestine - there were many fierce political conflicts in the world. And there was an enormous political repression emanating from these conflicts. In this sense everything was certainly neither up for grabs, nor possible. However, I think that the ways in which we, the radical students, actually succeeded in re-making curricula, gave me a very strong sense of the fragility of institutions, a sense of possibilities, a sense of horizons opening up, a feeling that institutions and curricula can be changed! A just-go-out-and-do-it-feeling. If you are a critical mass, you can do it! Because when I was a student, we basically created our own feminist curriculum. Coming from this very untraditional educational background turned me into a post-disciplinary scholar. I cannot say that I have a discipline, even though I have a degree in literary studies. Instead, I am a post-disciplinary feminist scholar, and I have been that since I started doing feminist research at the Department of Literary Studies at the University of Copenhagen in 1970's. Already back then, I thought that research problems ought not to emerge from narrow disciplinary niches but grow out of questions raised in activism.

I have brought the knowledge about the possibility of change in Academia - which came out of these experiences from the intersections of the students' and feminist movement - with me ever since. It has been crucial for my work to build up feminist studies throughout my second non/career. I really took the lesson back then that curricula can be changed from below - this shaped my whole academic career, which definitely was not a career in the more traditional sense of the word. I was, even hesitant about whether it was worthwhile to finish my MA degree in literary studies. It was only because my life partner Mette Bryld told me that she thought it would be better for my future possibilities for doing feminist research (which was what I passionately desired to do), that I actually completed the degree. Similarly, with my $\mathrm{PhD}$, or rather my old Danish doctoral degree of Dr. Phil., which consisted of 10 years work of independent research on feminism, psychoanalysis and queer subjectivities (Lykke, 1989). I never thought of it as something that would end up as a doctoral degree. I saw it as a strong political, epistemological, feminist revolutionary, theoretical, and epistemological work, which I needed to do. It was only in retrospect that I realised that I could also hand it in as a dissertation and obtain the back then very prestigious Dr. Phil. degree. But of course, it helped me in my second non/career that I did hand it in, again prompted by Mette who persuaded me by saying that it would contribute to the recognition of the emerging field of feminist studies.

If my activist non/career was the first one, my second one has been dedicated to the long march through the institutions. From the beginning of the 1980s, I took part in building up women's studies, as we called it back then. However, I personally preferred the name feminist studies, emphasising a link to feminist epistemology, and activism, rather than to the object of study: women or gender. My second career was really what the German student movement leader Rudi Dutschke labelled 'the long march through the institutions of power' (Dutschke, 1980); that is, transforming society radically by working from inside its institutions. This is what I have done since the beginning of the 1980's until my third non/career started, when I retired and became a professor emerita in 2016.

Throughout this second non/career, I was trying to create spaces for feminist studies at universities - first 20 years in Denmark, followed by 20 years in Sweden. The reason I moved from Denmark to Sweden in 1999 was that there was so much resistance and backlash in Denmark. In the 1990s, it was more or less impossible to 
implement feminist research and teaching agendas in Danish universities. I experienced that going across Øresund (the strait between Denmark and Sweden) - changing jobs from being an associate professor of gender studies in Denmark, to becoming a professor of gender studies in Sweden - was like going from being absolutely no-one in terms of how I was looked upon in academia, to becoming a recognised expert.

Doing feminist research and teaching in Denmark was considered old-fashioned and boring. "Why the hell do you do it?' That was how I was met. Even though I had written this 700-page doctoral dissertation on feminism, psychoanalysis and queer subjectivities, and considered myself an expert on gendered and queer subjectivities. I was not praised for my work in Denmark. However, when I moved to Sweden, I became a celebrated expert overnight! I was the same person - my knowledge and skills were the same - but how I was met in academia (outside of feminist circles) and in the general public was radically different in the two countries. The conditions in Sweden were just so much better! Together with colleagues, I got the possibility to set up a PhD Program in Interdisciplinary Gender Studies at Tema Genus, the Gender Studies Unit at Linköping University, where I have been employed since 1999. Today, 20 years later, we have awarded $29 \mathrm{PhD}$ degrees in Interdisciplinary Gender Studies, and our first PhD, Cecilia Åsberg, is now professor in the Unit.

We have also set up an International Excellence Centre for Feminist Research (in collaboration with Gender Studies at Örebro University and Karlstad University) which, over the years, has hosted over 200 feminist researchers from all over the world through periods of residence. Tema Genus currently has four professors in gender studies; one in postcolonial feminisms, one in gender and neuroscience, one in gender and society, and one in gender, nature and culture. Compared to the two tiny offices we had for the Gender Studies Centre at the University of Southern Denmark, the contrast has been immense. So, if the lesson learnt from my first activist non/career was about the fragility of the institutions, the one I took from my second non/career and the work to institutionalise feminist studies in academia, was how big a role the social context plays. Denmark was definitely not the right place to do feminist research in the 1990s and 2000s, but Sweden was! Therefore, do not despair when the country you are in is totally [raises her middle finger]. Try instead to go for a job elsewhere.

Now, jumping quickly to my third non/career. In Sweden you have to retire when you turn 67 . You get an official letter from the university telling you that you have to send in your letter of resignation. They send you this letter three months before you turn 67. My colleague, Professor of Gender and Knowledge Production, Margrit Shildrick asked me, 'What happens if we do not retire?' We posed that question to the HR department, and were told that then we would probably be fired for lack of cooperation! So, indeed, it was an offer we could not refuse! All the Swedish emerita/emeritus-professors knew this, it was only non-Swedes such as Margrit and I, who had not understood that you had to resign yourself, because otherwise it would qualify as ageism, which is illegal in Sweden. Nevertheless, now I am enjoying being an independent researcher who can do, write and say whatever I like. I do not have to send in applications to get money from neoliberal funding agencies. I do not have to subscribe to the cruel optimism about topics I am not totally fond of, but which may attract funding to my department. I do not have to spin applications in order to get money out of funding agencies. Now, I can write poetry and dedicate myself to dig deep into the research I really care for without doing admin-work, I can delve into crip, queer, feminist, de-colonial, and posthuman studies. I can do whatever I like. I am very happy about this third non/career.

\section{Changes in Conditions - Threats to Feminist Research and Methodologies}

BRAIDOTTI: My generation challenged the political ideal of equality and highlighted the difference that feminist activists and philosophers can make to actual academic practice. Most of us actually left philosophy as an institutional site and settled for new interdisciplinary fields (Braidotti and Butler, 2010); I never held a job in philosophy, nor felt accepted or respected by academic philosophy. The institutional friction between my generation of feminists and philosophy departments was never resolved. I still love the archive of that discipline, though, and keep re-reading core texts.

My academic career started as a pioneer in women's studies in Utrecht in 1988. It was a challenge to steer a professional course as the founding professor of women's studies at Utrecht University in the midst of the end of the Cold War era. Although I had great role models in some of the American women's studies leaders, such as Kate Stimpson, Nancy Miller and Joan Scott, in the European context I and my allies had no set paths to follow. The previous generation of feminists, who came of age in Europe in the 1950s and 1960s like de Beauvoir, had settled into an ambiguous relationship to the academic world by identifying with masculine universalistic intellectual positions. This older generation dialogued more readily with the great male philosophers of the past, than with living women, let alone forging alliances with their own peer-group. Working together for the institutionalisation of women's studies allowed us to change that. I believe that gestures of feminist solidarity within institutional work was the transformative moment. It allowed the students to enjoy the institutional presence of supportive feminist teachers and supervisors, who would train them rigorously, while supporting their radical projects. We started using the scholarly apparatus as a tool to consolidate feminist theories and knowledge claims. 
Teaching is the ideal way to transmit the feminist genealogical capital and to empower the critical independence of minds of younger generations. After setting up BA and MA teaching programmes, by 1995 we established the first $\mathrm{PhD}$ training programmes in Utrecht, which required official certification by the Royal Dutch Academy of Sciences. Getting that recognition was a breaking point, which allowed us to start the Netherlands Research School of Women's Studies and produced dozens of $\mathrm{PhD}$ dissertations. The inter-generational impact is huge, just consider that, two of my former PhD students - Sandra Ponzanesi and Iris van der Tuin - went on to become full professors in Utrecht themselves. That is true feminist genealogies at work!

The international context after the end of apartheid, was dominated in my world by the twin phenomena of the fall of the Berlin wall in 1989 and the enlargement of the European Union. It was also punctuated by a new wave of wars: the first Gulf war, the Falklands war, and the Yugoslav and Balkans war had a major impact on the development of continental and transnational feminism. My work as director of women's studies was transEuropean from the start. Together with dear colleagues like Nina, we set up the Erasmus teaching network NOISE in 1993 with funds from the European commission. It is still going today as a self-funded network. Building on that success, we were asked to advise the commission on matters of gender equality in education, which led to the creation of the Socrates Thematic Network ATHENA in 1996, of which I became the founding director. In 2010 it received the Erasmus Prize from the European Commission. And then came the first 'Gender Graduates', Marie Curie Early Stage Training consortium in 2005 to 2006. There's no under-estimating the quality and the quantity of the work I and my colleagues did to network feminist Europe. We were pioneers in this kind of transnational education.

My institutional practice echoed the nomadic theoretical project as a critique of Eurocentrism from within, and a way of activating the centre away from inertia and self-replication. I undertook the European feminist project as a critique of Eurocentric whiteness and a rejection of methodological nationalism (Beck, 2007), thus joining in a planetary debate which black, anti-racists, post-colonial and other critical thinkers put on the map.

Therefore, the fact that I never made a career plan does not mean that I did not think seriously about what practice would best suit my political passions and intellectual talents. Migration has shaped my life, with immense shifts first from Italy to Australia, then back to Europe in Paris and finally into the Netherlands. This non-linear path is crucial, as it implies a series of creative disconnections - it wrote internationalism into my personal and professional script from the beginning.

\section{The Rise of Cognitive Capitalism}

BRAIDOTTI: A lot changed with the new world order in 1989, the so-called triumph of capitalism and the 'end of history' (Fukuyama, 1992) with the rise of neo-liberal economics. These mutations challenged, the Hegelian-Marxist axiom that history had its own teleological logic, which confronted its contradictions of capitalism in a dialectical mode in the pursuit of breaking points. This axiom was central to the feminist socialist and radical projects as well. It rested on the assumption that capitalism could not continue to sustain such flagrant injustices and that it would eventually break. This idea was rejected by my philosophical teachers: Foucault like Deleuze, and Derrida to a certain extent, called into question the logic of dialectics and the inevitability of the breakdown of capitalism. They drew the consequences of the relative failure of the students' revolution of ' 68 , which was a great cultural revolution, but less successful as a political one.

That generation of French thinkers, which included major feminists like Irigaray and Cixous, as well as Francophone Arab feminists like the Moroccan Fatima Mernisi and Assja Djebar - who was Algerian and a member of the Académie Française - drew the consequences of this, calling the Hegelian and Marxist political position to accountability.

This resulted in a change of paradigm that had a big impact on my work. I strove to move towards corporeal new materialism, closer to Spinoza's insight about vital matter and non-essentialistic naturalism. These ideas were central to the post-structuralist philosophies. The problem is that their political punch was lost in translation, when the Americans repackaged them as 'French theory', focusing almost exclusively on the linguistic turn of Lacan and Derrida. This created the American school of 'French Theory', centred on semiotics, psychoanalysis and deconstruction (Redfield, 2016).

What was left out, in the creation of 'French theory' was all the neo-materialist line of thinking, which entails the critique of dialectics and hence proposes a different reading of capitalism and of resistance to it. A true change of paradigm towards what Deleuze and Guattari (1972) called 'capitalism as schizophrenia', that is to say a system that shows the adaptable capacity to sustain even the most strident contradictions without breaking. Why? Because capital - as well as the resistance to it - are not transcendental notions, but rather radically immanent ones. That means we are part of the very problems we are critiquing. Oppositional consciousness does not extract or exonerate us from the conditions we are against - we are part of one, common matter, which is environmental social and affective and these multiple ecologies of belonging also structure the work of critique. This relocation of the function of the negative is the defining trait of radical Spinozism. It intersects perfectly with radical feminism, 
when it argues that the personal is the political, that locations are grounded, embodied and embedded, and that solidarity is critical to compose subject formations as transversal alliances. That is the groundwork of my research.

What matters here for the status of the university is the analysis of the mutation of capitalism. As early as 1979, Pierre Macherey wrote about the paradigmatic switch from Hegel to Spinoza. For me, to be able to detect these changes in the system and assess how they impacted upon the practice of radical epistemologies like feminism became a priority. So, where does this mutation leave the long feminist march through the institutions? If the contemporary university has become co-extensive with cognitive capitalism, it must admit that knowledge nowadays is produced everywhere: in corporate locations like Google labs, Apple campuses, Netflix studios, and Amazon franchises, in the art world, in activist organisations like citizens' science. This means that we do not need to be in a university to produce knowledge or initiate scientific research. To deal with this, we need new cartographies of power, to account for new modes of knowledge production and what kind of subjects we are in the process of becoming. And my perennial concern is: how are we reproducing hierarchies of power? Are we reproducing the very system that we are trying to fight? The university reacted to the rise of neoliberalism by reconstructing itself through a double move. On the one hand the academic star system, which really starts in the 1990s, and on the other the precariousness of the teaching labour force, thus creating a pyramidal structure. The diversification of the once classical professorships into a range of different kinds of professors over the last ten years is indicative of this shift.

But you see massive transformations everywhere, for instance the blatant marketing of neoliberal feminism making it into a corporate issue on individual empowerment and financial success. That happens just as the equal opportunities policies switch to gender mainstreaming, taking the radical edge out of feminist practice and making it compatible with the re-organisation of the economy. Today we have the whole 'diversity' mantra to deal with. It is necessary to a certain extent, but is it transformative enough?

LYKKE: Well, on one hand, you are right; that the students' revolt of 1968 failed, or rather I would say that its results were co-opted by neoliberalism. But on the other hand, I think that ' 68 really made an impact, I would say that the feminist branch of ' 68 of which we were part, had an impact on academia in an everyday utopian sense. But it also made some strange alliances with neoliberalism. Seen from a neoliberal point of view, I think that what the students' movement of ' 68 did was to wipe out an outdated academic system - the old academic hierarchy with professors in charge of all decision-making, having absolute power and authority to keep up often very oldfashioned and outdated curricula instead of reorganising the university in terms of being useful to society. This agenda about being useful to society, 'research for the people, not for profit' was what we demonstrated for in the 1970s. And I think our activist work gave impetus to new critical research agendas - feminist, queer, postcolonial, anti-racist, post-human, crip and post-socialist research agendas - the agendas of all the radical studies that emerged from the institutional arenas, and made the changes happening in the 1970s in the wake of ' 68 possible.

However, unfortunately, the new agendas were also co-opted and twisted by neoliberalism, so 'useful for society and the people' ended up meaning 'useful for neoliberal capital', and this was, of course not what we intended when we demonstrated for university reforms and new critical curricula in the 1970s. But strange alliances emerged along the way. Some European countries, among others in Eastern and Southern Europe, kept up the old system with massively long degrees instead of shorter stream-lined modules, which eventually became the neoliberal mantra for effective academic education. And, in the universities which kept up the old-fashioned, hierarchical system with long degrees and a lot of professorial power, it has been much more difficult to implement gender studies. Therefore, paradoxically, in the countries where neoliberalism actually has been more advanced in universities, such as Sweden for instance, it has been easier for gender studies to enter the academic scene. Ideology did not matter so much there. If you could attract 500 students for each module in the neoliberal university, then everything was fine. 'If students or external funds pay what you are doing, great, then just go ahead and do it!' was what we were told by neoliberal university managers. No focus on ideology here. In the old system, by contrast, you were rejected, because feminist and radical anti-capitalist epistemologies were not accepted.

I am caricaturing a bit, but what I am saying is that in the new, neoliberal system it was numbers that counted rather than ideologies, and paradoxically, this made it easier to bring in gender studies. We had the big European Athena Network (in the 1990s and 2000s) that Rosi successfully coordinated for many years, and which at some point included over 100 universities running Gender Studies Programs all over Europe. In the context of this network, we developed the idea about twisting the neoliberal agenda from feminist perspectives. You may say that in one way neoliberal academic organisations used us, but in another way, we also used the university: we went in and twisted the neoliberal agendas, using them for critical feminist purposes. We talked about speaking EU language but doing it with a feminist twist. I myself invented the slogan of doing 'feminist hit and run interventions' into the neoliberal university, when we set up summer schools, journals, courses in feminist epistemology, feminist theory, and other radical things - basically initiating learning processes that heavily criticised neoliberalism from feminist points of view. 
There was a strange alliance with neoliberalism. I have been writing about this process (Lykke, 2017b), trying to come to terms with the dilemmas and the contradictions through the lens of two notions; on the one hand, Lauren Berlant's notion of cruel optimism (Berlant, 2011), implying that you produce an optimism that only exists at the surface, to which you are attracted, while erasing the underlying problems. I think we became very good at navigating in the messy waters between performing cruel optimism, and on the other hand, twisting and turning neoliberal agendas, making space for the unfolding of everyday utopianism - an important notion coined by Davina Cooper (2014). I think there were spaces where we succeeded at twisting the neoliberal agenda and doing things critically and differently - I think that all the very radical and critical feminist $\mathrm{PhD}$ theses which came out of the institutionalisation of $\mathrm{PhD}$ degrees in feminist studies testify to this. And I think what you [pointing to Lea Skewes who founded Gendering in Research at Aarhus University] have been doing here in Aarhus is also that sort of twisting the neoliberal agenda. So, I think we need to think about the long march through the institutions of power as this messy mix of cruel neoliberal optimism and critical feminist twisting of agendas, creating everyday utopianism. This is for me 'feminist hit and run interventions' into the neoliberal university.

However, I think it is also important to be aware that a new situation is emerging today, where the growing right-wing seems to be changing the agendas, and ideologies are coming back. While the neoliberal managers basically do not care about ideologies as long as you can prove that you earn money, the raising right-wing is different, and I think it is very important to be aware of this difference. Viktor Orban threatened to put a ban on gender studies teaching in Hungary - the two gender studies programmes in that country are targeted specifically. In Sweden, the right-wing party, the Sweden Democrats, is arguing along similar lines. The party has specifically targeted gender studies and anti-racist studies. The Sweden Democrats got 17 per cent of the votes in the last Swedish parliamentary election, September 2018. Fortunately, it seems as if all other political parties in Sweden are so far bent on keeping an arms-length to the Sweden Democrats.

I have recently, together with colleagues in Sweden, replied to an attack on Swedish gender research by two researchers from the University of Umeå (Lykke, 2018). These researchers have in a pseudo-scientifically-objective way argued that the Swedish Research Council has given far too many resources to gender studies in recent decades (Madison and Söderlund 2018). To argue this, they collected a database of gender studies publications and other publications on gender/sex from the period from 2000-2011, coming to about 12,000 items. They then selected small samples from the database, trying, in different ways, to bibliometrically 'prove that gender studies publications represent bad science and low-quality research. The articles by the two anti-feminist researchers from the University of Umeå are published in a well-established, international bibliometric journal called Scientometrics, even though the methods and results are biased and invalid due to their disrespect for differences between quantitative and qualitative research. These kinds of pseudo-scientific attacks on gender studies are not specific for Sweden, and not new, but I think that they coupled with right-wing ideological attacks indicate a new situation, which it is important to take into account. The fight against the rising right-wing is different from the one we have been fighting for years against neoliberal agendas.

BRAIDOTTI: I completely agree that the regression of nativism is massive. It is extraordinary that it should come up North - in the second world war this was the anti-fascist region - apparently not anymore. We need to make anti-fascist alliances and study the contemporary form of an old virus. But I want to take up the issue about the attack on the scientific quality of our work, which is part of a larger attack on the humanities and the social sciences. This is partly one of the sub-effects of neoliberalism, which by foregrounding big data, introduces methodological coercion to a flat form of empiricism. I have always argued that feminist philosophy with politics of location, and the idea that the personal is political, is an enlightened or enchanted version of empiricism. Think for instance of Irigaray's sensible transcendental, or Deleuze's empirical transcendental. If there is anything that is empirical, it is the complexity of the embodied and embedded. The methodological frontline is there. Unfortunately, neoliberalism itself has decided that humanities and social sciences are useless. And the cut-backs on this date back a few decades. But for me it is part of a broader attack on the foundation of feminist studies. We have succeeded in the Humanities and Social Sciences. If you look across the spectrum of the new environmental, digital and medical humanities - all established branches of the contemporary post-humanities - you will see that they hardly include feminist epistemologies, race and postcolonial theories. This is not the case of course with the feminist post-humanities.

We now have a new generation of feminist scholars - a lot of them coming in through the Sciences and encountering gender issues. But the gender issues are disconnected from their scientific work. What the feminist post-humanities can offer is transversal methodologies, based on immanence, the politics of locations and the determination to negotiate with neo-liberal governance in the academic world. You cannot easily do the same feminist epistemologies that we developed over the last decades - we need to transpose them into new research frameworks, collaborative scientific ways of knowing and new forms of empiricism. The way to handle these issues is to start from the project of composing a 'we' that is grounded, accountable and active. In the midst of our 
technologically mediated social relations and in response to the paranoid rhetoric of our post-truth democratic leaders, how can we labour together to construct affirmative ethical and political practices? 'We' need to reradicalise ourselves.

\section{Hit and Stay Interventions}

LYKKE: It was a radical move when we as feminists moved inside university institutions to change them, and today, as well, I think it is worthwhile to try to work with activist agendas from within neoliberal and otherwise oppressive institutions. I have argued for many years that the links between theory and activism are extremely important, and that feminist theory, and feminist epistemology are dependent on a constant anchorage and dialogue with activism. But additionally, I think the link to professional use of critical knowledges is crucial. I am teaching a module at our Linköping master programme in Gender Studies - Intersectionality and Change, where we discuss how theory/activism-links can be used as inspirations for professionally transformative work in workplaces (Lykke, 2017a). This relates to the changing of institutions, which we have been discussing today under the label of 'the long march through the institutions of power'. In my generation, to establish professorships, $\mathrm{PhD}$ programmes, and master programmes in feminist studies was a major challenge. This work was really about 'the long march through the institutions' in terms of actually changing workplaces, changing university institutions, changing the doings of institutions, changing the doing of epistemologies in institutions, and the doing of teaching. I see institutions as fragile, but they are at the same time solid, which makes change difficult, painful and full of dilemmas.

One of the skills, discussed a lot in the aftermath of 1968, was critical social fantasy (Lykke, 2017a). I think that this skill can be generated through feminist studies, by building up theories which are interlinked with activism, but I also think that this skill can be used to do transformative work in institutions, inside and outside of academia. Instead of leaving it to conventional people to manage institutions, it is important that people with skills in using critical social fantasy take responsibility for transformative work. But of course, one needs to be careful, which is why I am stressing the need to navigate between the cruel optimism of neoliberal agendas, and feminist everyday utopianism. While doing activist work, you need to be aware of dilemmas and traps, and have communities around you to collectively discuss how to handle these.

In the module which I have been teaching and developing in our master programme in Linköping - we among others use collective models from revolutionary theatre (Boal, 2008) to try out discussions around the problems arising when one tries to grapple with transformative work in institutions and organisations.

BRAIDOTTI: I come to the same conclusions from a different angle: immanence. We are immanent to the very conditions we are trying to change - this is not the Hegelian-Marxist dialectics. When you are against, you are not outside the problem: that would be too easy. Advanced capitalism works because it works for us! Because we cannot do without an iPhone, and it has to be an Apple doesn't it? Because we don't go down to town to keep the shops going, we order it on Amazon. It is us! So, I think being immanent to the conditions you are trying to overturn - this is feminist politics of locations, and this is radical immanence, with Deleuze and critical Spinozism. The question is what kind of margins we can negotiate through alliances but also through our own process of disidentification with the practices that we are engaged in. Ethics is detoxing from negativity. When I take in the world I also take in the poison, the pain of the world. Spinoza speaks about poison - the poison of violence and vulgarity - which for us now is the neo-fascists, the populists, the nativists. So, we are part of this system, which we strongly oppose. How far can we detox? How far can we disengage?

We need to speak from potential and strive to make a change in the world. I think it is those negotiations that require communities, they require alliances, and the allies are in the most absurd places. What would be the feminist intervention in a corporate feminist world with Lagarde and stars like Emma Watson and He-for-She at UNESCO? We have Pussy Riot and the pink pussy hats. We have the LGBTQ+ movement, \#MeToo and Black Lives Matter. We have the Women's Movement in India and South Africa. The allies may not be in the places you expect them to be. So, I think we need to enlarge our relational capacity, the affective barometer assessing who we can draw on. We should not think in us versus them, but transversally and collaboratively. The market may be a stronger ally at this point in time than we may think, especially when compared to the conservative nationalism of so many humanities faculties across Europe.

\section{Making Feminist History}

LYKKE: It is important to note that 1970 by the widely proliferating anti-capitalist and anti-establishment feminist movement was announced as the year zero of feminism (Delphy, 1970). However, I did a project together with my partner Mette Bryld and several other feminist colleagues (Bryld et al, 1982) on the period of 1880-1920 in Europe and the broad feminist, socialist and queer (avant la lettre) movements at that time. A lot of feminist theorising and writing did take place back then but then vanished due to lack of archiving. In the 1970s when I 
started to do feminist studies, like you, Rosi, I also read Kate Millet and Germaine Greer, and we had a list of about 10 books in total on the reading list for our women's studies courses back then - that was it. However, I later found out that there were large numbers of important books from the period 1880-1920 which were just not accessible, not archived properly, nowhere to be found unless you dug really deep.

BRAIDOTTI: In the long march through the institutions it was understood that the universities are archives what we today call databanks - a place where knowledge is canonised, institutionalised, and preserved. There was this sense of bringing back the women and the LGBTQ+ people. The first thing we did was women's and gay history courses; her story. We wrote the women back in. We have always been there. But we have always been deleted. The hope was that through the institutional processes at least some bits of it would be preserved. I think my generation has a political responsibility to archive our papers and put them safely away for future generations to consult, analyse and be inspired by. Therefore, I work closely with the International Archive of the Women's Movement in Amsterdam, to archive both institutional and personal material. How do we secure what we have done in the institutions? How do we make sure it stays in the institutions? As for my private archive I have agreed that when I die they will come and take it. I have a life-long diary, which is sort of my second life on paper.

As much as I love the university as institution - what is knowledge production today? Digital artisans? It is time to develop a critical theory for anti-fascist citizenship, although that may not get you a research grant. Speaking truth to power, from within!

LYKKE: I am worried about the precarious conditions of people in academia today, and that it is getting increasingly worse - especially for academics who are pursuing careers in critical studies such as feminist studies and researching issues that are controversial. Rosi, you took the discussion to a broader reflection about the humanities and the social sciences, and this is important, too, but I think that when you are doing things on the margins of the humanities and the social sciences - doing controversial issues such as feminist studies - you are in an even more precarious position than when you are doing conventional stuff. Academic precarity is taking on new forms today. In the 1970s and 1980s, people simply left academia, eventually to get other kinds of jobs, if they did not get a permanent position in academia, which very few people doing controversial work did. What is happening now, is that the neoliberal system with short-term contracts produces a lot of cruel optimism, which somehow keeps people aspiring to get a job in academia: 'I will just submit one more application, and this time, I will get the money'. People are encouraged to stay on, even though it is difficult to get the short-term contracts. The system makes people stay; it produces this attachment to apply and re-apply - which we with Lauren Berlant's term (2011) can call cruelly optimist. This means that universities and other research organisations - cognitive capitalism - get an enormous creative, labour force reserve who have all kinds of critical social fantasy skills, and who are well versed in doing all kinds of things that are extremely needed, but which cognitive capitalism does not want to pay a permanent, full-time wage for. Instead universities take people in on short-term contracts, and when people keep running after those contracts, the wheels of the system keeps running. I am writing at least three recommendations for people per month for scholarships and positions. I take seriously my responsibility as feminist professor acting as a gate-opener rather than a gate-keeper. It is important to do all the things that we as feminist professors can do to support the next generation of feminist researchers in their endeavours. But I also think that the way in which neoliberal universities profit from this enormous academic labour force reserve is very problematic. Yet, going back to the fragility of the institutions and back to thinking along the lines of '68, I am still optimistic, because many students are protesting all over the world. Students' movements have not been so powerful in Denmark in recent years, though, but I think that in many other places there are powerful students' movements. I think what is needed is critical mass, and I hope to see powerful intersectional movements protesting against neoliberal conditions. We cannot do it effectively in a small group, but if we have a critical mass, it has an effect. I think that 1968 with all its limitations demonstrated this.

BRAIDOTTI: It has changed the world, but a lot of feminist scholars today are not located in gender, feminist or queer studies programmes.

LYKKE: A lot of these students' risings that we have seen all over the world more recently in e.g. Chile and South Africa have effects. Things are still alive and kicking. The ultimate lesson I will draw from my feminist engagement in the ' 68 movement, is that a critical mass and movements are extremely important. Not authoritarian structured movements, but intersectional movements which take internal difference and transversal politics seriously. I think the failure of communism showed how hierarchical movements with one blueprint for the future is a no-go. But ' 68 was different - in particular, because the feminist ' 68 s forcefully opted out of and criticised all hierarchical and authoritarian gestures of the movements. We need intersectional movements, committed to transversal politics, and here I think it is interesting that Patricia Hill Collins (2017) in her recent work on Black 
Lives Matter has shown how intersectionality and transversal politics are really influential, making the movement very strong. I think a way forward is to build on and take internal differences seriously, and create criticallyaffirmative, non-hierarchical mass movements.

BRAIDOTTI: But would you still apply for a university job today if you were 30, Nina?

\author{
LYKKE: Mmm...
}

BRAIDOTTI: Should I answer my own question? I would truly hesitate to enter the university today. If I were to start again, I would be outside doing negotiations looking in. Solidly planted in cognitive capitalism and looking in, because cognitive capitalism does knowledge production better than the university, though it is obsessed with profit. And then the negotiations can start. I would be answering Steven Bannon with another foundation - finding the allies, the money. There is progressive money out there. We need to practice activism in terms and conditions that repurpose both our collective inscription in and resistance to cognitive capitalism.

LYKKE: I think that I would rather once more commit myself to activism, in particular arts activism, than apply for a job at a university, but I also know it is easy to say this, when I have my retirement money.

BRAIDOTTI: I have two other desires; I want my own foundation and my own satellite. It would make me able to beam out our feminist knowledge. I want a progressive satellite, and a foundation that can counteract right wingers, and force the universities to take a stand against rising liberal forces. I want them to speak up and say that this nativist fascism is not worthy of The Netherlands, Sweden, and Denmark - the great democracy of the North. Why can't we have vice-chancellors who say that?! Until that happens, I am very sceptical that the university still exists as an independent entity devoted to democratic criticism and the construction of discerning citizens.

\title{
REFERENCES
}

Adrian, S. W., Skewes, L. and Schwennesen, N. (2018). Introduction to Feminist STS at Work: Challenging Dichotomies and Privileges. Women, Gender \& Research, 1, 1-14. https://doi.org/10.7146/kkf.v27i1.106340

Beck, U. and Grande, E. (2007). Cosmopolitanism: Europe's Way Out of Crisis. European Journal of Social Theory, 10(1), 67-85. https://doi.org/10.1177/1368431006068758

Berlant, L. (2011). Cruel Optimism. Durham and London: Duke University Press. https://doi.org/10.1515/9780822394716

Blaagaard, B. and van der Tuin, I. (eds.) (2014). The Subject of Rosi Braidotti. Politics and concepts. London: Bloomsbury Academic.

Boal, A. (1979/2008). Theatre of the Oppressed. London: Pluto Press.

Braidotti, R. (2006). Transpositions. Cambridge: Polity Press.

Braidotti, R. (2011). Nomadic Subjects: Embodiment and sexual difference in contemporary feminist theory. New York: Columbia University Press. https://www.jstor.org/stable/10.7312/brai15388

Braidotti, R. (2014). The Untimely, in B. Blaagaard and I. van der Tuin (eds). The Subject of Rosi Braidotti. Politics and concepts. London: Bloomsbury Academic.

Braidotti, R. and Butler, J. (2010). Out of Bounds: Philosophy in an Age of Transition, in R. Braidotti (ed), The History of Continental Philosophy, 7 (pp. 307-335). Durham: Acumen. https:/ / doi.org/10.5040/9781350250284.ch-010

Braidotti, R., Mazzanti, R., Sapegno, S. and Tagliavini, A. (2003). Baby-Boomers: Vite parallele dagli anni cinquanta ai cinquant anni. Firenze: Giunti.

Bryld, M., Lykke, N., Hjordt-Vetlesen, I-L., Ballegaard Petersen, A. and Rosenbeck, B. (eds.) (1982). Overgangskvinden. Kvindeligheden som historisk kategori - kvindeligheden 1880-1920. Skriftserie fra Arbejdsgruppen for Kvindestudier, bd. 1, Odense: Odense Universitetsforlag.

Cooper, D. (2014). Everyday Utopias. The conceptual life of promising spaces. Durham and London: Duke University Press. https://doi.org/10.2307/j.ctv1220qrp

Deleuze, G. and Guattari, F. (1972). Anti-Oedipus: Capitalism and scbizophrenia. Minneapolis: University of Minnesota.

Delphy, C. (1970). L’ennemi Principal, Libération des Femmes. Année Zero. Partisan, 54-55, 157-173.

Dutschke, R. (1980). Mein langer Marsch: Reden, Schriften und Tagebücher aus zwanzig Jabren. Hamburg, DE: Rowohlt.

Fukuyama, F. (1992). The End of History and the Last Man. New York: Free Press.

Hill Collins, P. (2017). On Violence, Intersectionality and Transversal Politics. Ethnic and Racial Studies, 40(9), 14601473. https:// doi.org/10.1080/01419870.2017.1317827

Lykke, N. (1989). Rodhatte og Ødipus: Brikker til en feministisk psykoanalyse. Odense: Odense Universitetsforlag.

(C) 2021 by Author/s 
Lykke, N. (2017b). Academic Feminisms: Between Disidentification, Messy Everyday Utopianism, and Cruel Optimism. Feminist Encounters. A Journal of Critical Studies in Culture and Politics. 1(1), 1-12. https://doi.org/10.20897/femenc.201703

Lykke, N. (2018). Can’t Bibliometric Analysts Do Better? How Quality Assessment Without Field Expertise Does Not Work. Scientometrics, 2018(117), 655-666. https://doi.org/10.1007/s11192-018-2872-x

Lykke, N. and Braidotti, R. (1996). Between Monsters, Goddesses and Cyborgs. Feminist confrontations with science, medicine and cyberspace. London: ZED.

Lykke, N. (2017a). Imagining Professional Futures in Feminist Classrooms, in E. Just and W. Grahn (eds), Theories of Affect and Concepts in Generic Skills Education. Adventurous encounters (pp. 191-211). Newcastle upon Tyne: Cambridge Scholars Publishing.

Macherey, P. (1979/2011). Hegel or Spinoza. London: University of Minnesota Press. https://doi.org/10.5749/minnesota/9780816677405.001.0001

Madison, G. and Söderlund, T. (2018). Comparisons of Content and Scientific Quality Indicators Across PeerReviewed Journal Articles with More or Less Gender Perspective: Gender Studies can do Better. Scientometrics, 115(3), 1161-1183. https://doi.org/10.1007/s11192-018-2729-3

Millett, K. (1970). Sexual politics: A Marxist appreciation. New York: Doubleday \& Company.

Redfield, M. (2016). Theory at Yale: The strange case of deconstruction in America. New York: Fordham University Press. https://doi.org/10.2307/j.ctt175x2jb

Skewes, L. and Adrian, S. W. (2018). Epistemology, Activism, and Entanglement - Rethinking Knowledge Production. Women, Gender \& Research, 27(1), 15-31. https://doi.org/10.7146/kkf.v27i1.109677

Citation: Skewes, L. and Adrian, S. W. (2021). The Long March Through the Patriarchal Institutions: A Dialogue Between Rosi Braidotti and Nina Lykke. Feminist Encounters: A Journal of Critical Studies in Culture and Politics, 5(2), 20. https://doi.org/10.20897/femenc/11156

Copyright (C) 2021 by Author/s and Licensed by Lectito BV, Netherlands. This is an open access article distributed under the Creative Commons Attribution License which permits unrestricted use, distribution, and reproduction in any medium, provided the original work is properly cited. 